\title{
Iodine Redox-Mediated Electrolysis for Energy-Efficient Chlorine Regeneration from Gaseous HCl
}

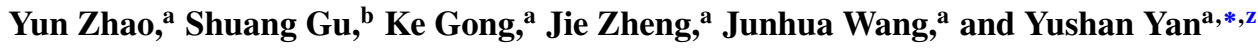 \\ ${ }^{a}$ Department of Chemical \& Biomolecular Engineering, Center for Catalytic Science and Technology, University of \\ Delaware, Newark, Delaware 19716, USA \\ ${ }^{b}$ Department of Mechanical Engineering, Wichita State University, Wichita, Kansas 67260, USA
}

\begin{abstract}
Hydrogen chloride $(\mathrm{HCl})$ by-product is often produced from chlorine-consuming processes. Traditional electrochemical processes for converting $\mathrm{HCl}$ to chlorine $\left(\mathrm{Cl}_{2}\right)$ are completed by anodic oxidation reaction coupled with cathodic reduction reactions (two major types: hydrogen evolution reaction and oxygen reduction reaction). Herein, a triiodide $\left(\mathrm{I}_{3}{ }^{-}\right) /$iodide $\left(\mathrm{I}^{-}\right)$redox-mediated cathode is implemented for the first time for converting $\mathrm{HCl}$ to $\mathrm{Cl}_{2}$. The iodide $\left(\mathrm{I}^{-}\right)$can be converted back to triiodide $\left(\mathrm{I}_{3}{ }^{-}\right)$by air in a reactor external to the eletrolyzer. The desirable redox potential and facile kinetics of $\mathrm{I}_{3}{ }^{-} / \mathrm{I}^{-}$offer a substantially lower operational cell voltage, reducing energy consumption by $20 \%-25 \%$ at a typical current density of $4 \mathrm{kA} \mathrm{m}^{-2}$ and improving the efficiency of $\mathrm{Cl}_{2}$ recovery.

(C) The Author(s) 2017. Published by ECS. This is an open access article distributed under the terms of the Creative Commons Attribution Non-Commercial No Derivatives 4.0 License (CC BY-NC-ND, http://creativecommons.org/licenses/by-nc-nd/4.0/), which permits non-commercial reuse, distribution, and reproduction in any medium, provided the original work is not changed in any way and is properly cited. For permission for commercial reuse, please email: oa@electrochem.org. [DOI: 10.1149/2.0461707jes] All rights reserved.

(cc) BY-NC-ND
\end{abstract}

Manuscript submitted February 9, 2017; revised manuscript received April 10, 2017. Published May 5, 2017.

As one of the most important industrial chemicals, chlorine gas $\left(\mathrm{Cl}_{2}\right)$ is used to synthesize numerous consumer products and useful intermediates. ${ }^{1}$ Chlorination of alkanes or aromatics is a substitution reaction with hydrogen, for which only one chlorine atom $(\mathrm{Cl})$ is actually used to produce chloro-organics, the other chlorine atom being lost as hydrogen chloride $(\mathrm{HCl})$ by-product. While the demand for $\mathrm{Cl}_{2}$ rapidly rises, the $\mathrm{HCl}$ market is oversaturated. As such, on-site $\mathrm{Cl}_{2}$ regeneration from $\mathrm{HCl}$ is increasingly desirable. Conversion from $\mathrm{HCl}$ to $\mathrm{Cl}_{2}$ can be achieved via classic chemical reactions based on the Deacon reaction using a heterogeneous catalyst, but high temperature (e.g., $250-350^{\circ} \mathrm{C}$ ) and complex reactor design are needed to mitigate intrinsically low reactivity and yield. ${ }^{2-4}$

Alternatively, an electrochemical process is preferred via an electrolyzer with a simple modular design that can operate at mild operating temperatures and be scaled out easily. To complete the electrolysis process, anodic regeneration of $\mathrm{Cl}_{2}$ from $\mathrm{HCl}$ must be balanced by a cathodic reaction. There are two major types of cathodes used in $\mathrm{HCl}$ electrolysis: the hydrogen evolution cathode (HEC) (Eq. 1), and the oxygen reduction cathode (ORC), also industrially called oxygen depolarized cathode (ODC) (Eq. 2).

$$
\begin{gathered}
2 \mathrm{H}^{+}+2 e^{-} \rightarrow \mathrm{H}_{2} \quad 0.00 \mathrm{~V} \text { vs. SHE } \\
\mathrm{O}_{2}+4 \mathrm{H}^{+}+4 e^{-} \rightarrow 2 \mathrm{H}_{2} \mathrm{O} \quad 1.23 \mathrm{~V} \text { vs. SHE }
\end{gathered}
$$

HEC-based electrolysis can produce $\mathrm{H}_{2}$ as a valuable by-product but ODC-based electrolysis offers significantly lower standard cell voltage due to its high redox potential (1.23 V vs. SHE).

Both aqueous $\mathrm{HCl}$ solution and $\mathrm{HCl}$ gas can be the feedstock at the anode of the electrolyzer. Gaseous $\mathrm{HCl}$ is often more desirable than an aqueous solution, not only because gaseous $\mathrm{HCl}$ by-product is readily available from industry but also because it lowers the anode potential (chlorine evolution reaction) by $370 \mathrm{mV}$ (0.99 vs. $1.36 \mathrm{~V}$, SHE, for gaseous vs. aqueous $\mathrm{HCl}$ at standard conditions). In addition, the absence of water fundamentally eliminates the parasitic oxygen evolution reaction at the anode, drastically improving coulombic efficiency and suppressing electrode corrosion. The first proof of principle of gaseous $\mathrm{HCl}$ electrolysis was demonstrated by DuPont in 1995. ${ }^{5,6} \mathrm{~A}$ fuel-cell-type electrolyzer was used in the process with an HEC. Later, an ODC was also employed as well in the gaseous $\mathrm{HCl}$ electrolysis process, as claimed in the patent by DuPont. ${ }^{5}$

\footnotetext{
*Electrochemical Society Member.

${ }^{\mathrm{z} E-m a i l: ~ y a n y s @ u d e l . e d u ~}$
}

Compared with HEC, ODC-based electrolysis can lower the standard cell voltage of gaseous $\mathrm{HCl}$ electrolysis. However, the operational voltage is still high because of the sluggish oxygen reduction reaction (ORR). Vidaković-Koch et al. indicated that the overpotential for anodic $\mathrm{HCl}$ oxidation is about $90 \mathrm{mV}$, but even with a platinum catalyst, the overpotential for cathodic ORR is about $800 \mathrm{mV}$ at a typical current density of $4 \mathrm{kA} \mathrm{m}^{-2}$.

The redox-mediated cathode has been considered as an alternative to $\mathrm{HEC}$ and ODC for $\mathrm{HCl}$ electrolysis. Iron $\left(\mathrm{Fe}^{3+} / \mathrm{Fe}^{2+}\right)$ redox mediation for $\mathrm{HCl}$ electrolysis was previously proposed by Low et al. in 1944. ${ }^{8}$ Herein we introduce $\mathrm{I}_{3}{ }^{-} / \mathrm{I}^{-}$redox mediation for gasesous $\mathrm{HCl}$ electrolysis. Opposite to $\mathrm{Fe}^{3+} / \mathrm{Fe}^{2+}$ redox that is based on cations, $\mathrm{I}_{3}{ }^{-} / \mathrm{I}^{-}$redox is based on anions, which intrinsically alleviates the problematic ionic crossover through the cation-exchange membrane (e.g., Nafion) in the electrolyzer. In addition, $\mathrm{I}_{3}{ }^{-} / \mathrm{I}^{-}$offers desirable redox potential and facile kinetics, similar to $\mathrm{Fe}^{3+} / \mathrm{Fe}^{2+}$.

Electrochemical reduction of $\mathrm{I}_{3}{ }^{-}$in an electrolyzer (forming $\mathrm{I}^{-}$) and chemical oxidation of $\mathrm{I}^{-}$in a chemical reactor (regenerating $\mathrm{I}_{3}{ }^{-}$) is shown in Figure 1. The overall processes are described as follows.

Electrochemical process:

$$
\text { Anode: } \quad 2 \mathrm{HCl} \rightarrow \mathrm{Cl}_{2}+2 \mathrm{H}^{+}+2 e^{-} \quad 0.99 \mathrm{~V} \text { vs. SHE }
$$

$$
\text { Cathode: } \mathrm{I}_{3}^{-}+2 e^{-} \rightarrow 3 \mathrm{I}^{-} \quad 0.54 \mathrm{~V} \text { vs. SHE }
$$

Chemical process:

$$
3 \mathrm{I}^{-}+\frac{1}{2} \mathrm{O}_{2}+2 \mathrm{H}^{+} \rightarrow \mathrm{I}_{3}^{-}+\mathrm{H}_{2} \mathrm{O}
$$

Overall reaction:

$$
4 \mathrm{HCl}+\mathrm{O}_{2} \rightarrow 2 \mathrm{Cl}_{2}+2 \mathrm{H}_{2} \mathrm{O}
$$

To the best of our knowledge, this is the first example of $\mathrm{a} \mathrm{I}_{3}{ }^{-} / \mathrm{I}^{-}$ redox-mediated cathode (TIRC) for electrolytic regeneration of $\mathrm{Cl}_{2}$ from $\mathrm{HCl}$ gas. Compared with HEC or ODC, TIRC has a desirable redox potential, $0.54 \mathrm{~V}$ vs. SHE, high enough for a low standard cell voltage $(0.45 \mathrm{~V}$ with a gaseous $\mathrm{HCl}$ feed $)$ and at the same time low enough for $\mathrm{I}^{-}$to be oxidized to $\mathrm{I}_{3}{ }^{-}$in ambient air. HEC has very high electrode activity (exchange current density, $i_{0}$, on $\mathrm{Pt}: \sim 10^{-1}$ $\left.\mathrm{A} \mathrm{cm}^{-2}\right)^{9}$ but a very low standard cathode potential $\left(p^{\circ}: 0 \mathrm{~V}\right.$ vs. SHE); ODC offers a high standard cathode potential ( $p^{\circ}: 1.23 \mathrm{~V}$ vs. SHE) but is very sluggish $\left(i_{0}\right.$, on Pt: $\left.\sim 10^{-10} \mathrm{~A} \mathrm{~cm}^{-2}\right){ }^{10}$ TIRC brings a moderate standard cathode potential $\left(p^{\circ}: 0.54 \mathrm{~V}\right.$ vs. SHE) and a high enough electrode activity $\left(i_{0}\right.$, on glassy carbon: $\left.\sim 10^{-2} \mathrm{~A} \mathrm{~cm}^{-2}\right)$ without requiring a catalyst. ${ }^{11,12}$ As a result, TIRC greatly lowers 


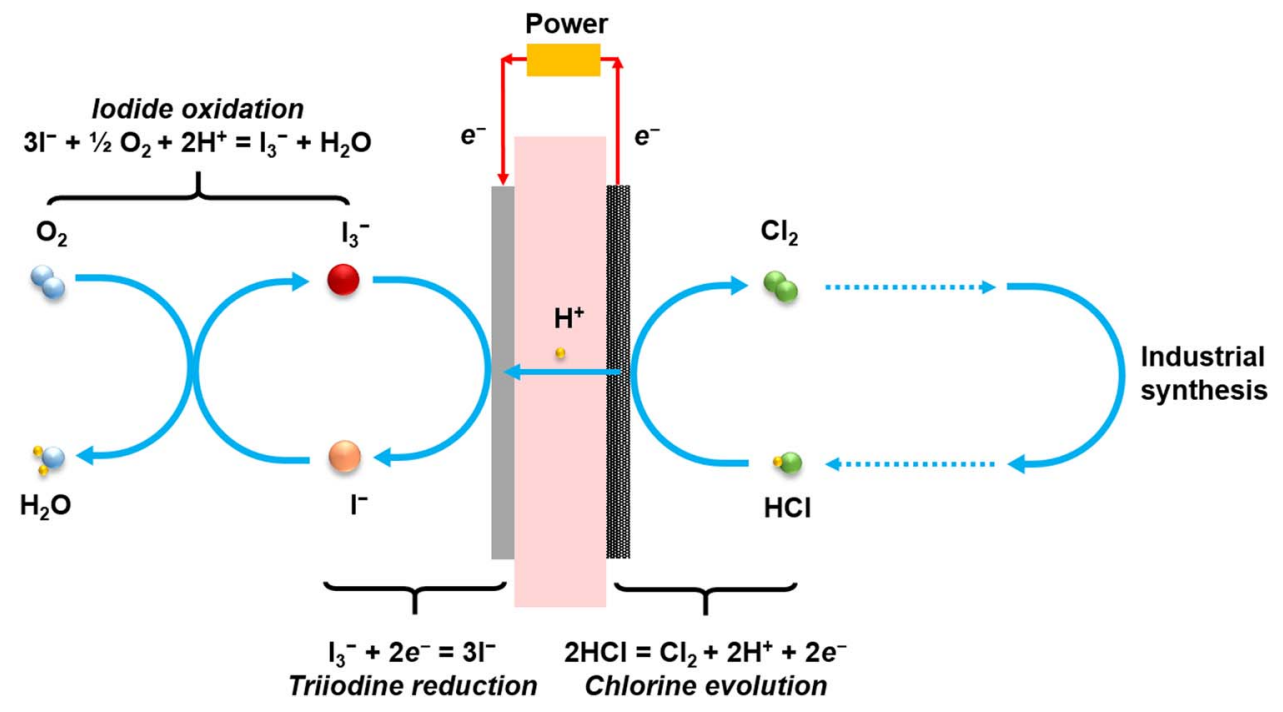

Figure 1. Working principle of triiodide reduction cathode (TIRC) electrolysis process using a gaseous $\mathrm{HCl}$ feedstock to regenerate $\mathrm{Cl}_{2}$. Electrochemical process: at the anode, $\mathrm{HCl}$ gas is oxdized to generate $\mathrm{Cl}_{2}$ gas and protons; and at the cathode, $\mathrm{I}_{3}{ }^{-}$is electrochemically reduced to form $\mathrm{I}^{-}$. Chemical process: $\mathrm{I}^{-}$is chemically oxidized to $\mathrm{I}_{3}{ }^{-}$by oxygen/air in a reactor external to the electrolytic cell and regenerated $\mathrm{I}_{3}{ }^{-}$is fed back to the electrolyzer.

the operational electrolyzer voltage, substantially reducing energy consumption.

\section{Experimental}

Iodide $\left(\mathrm{I}^{-}\right)$ions oxidation.-Oxidation of $\mathrm{I}^{-}$ions was carried out in a batch system consisted of magnetic stirring and temperature control. A mixed solution consisted of predetermined hydrochloric acid concentration and $3 \mathrm{M}$ potassium iodide (KI, Aldrich) was conducted in the batch system by bubbling air or oxygen to the bottom of the solution. Air and oxygen flow rates were determined as $800 \mathrm{ml} \mathrm{min} \mathrm{m}^{-1}$ and $200 \mathrm{ml} \mathrm{min}^{-1}$ through a rotameter, respectively. $\mathrm{I}_{3}{ }^{-}$concentration was calculated by titration with $0.1 \mathrm{M}$ sodium thiosulfate $\left(\mathrm{NaS}_{2} \mathrm{O}_{3}\right.$, Aldrich) at given time interval.

Cyclic voltammetry (CV) measurement of catholyte based on glassy carbon in RDE.-A polished glassy carbon electrode (effective area of $0.196 \mathrm{~cm}^{2}$, Pine Instrument) was immersed in the jacketed glass cell filled with iodine $(1 \mathrm{M})$, potassium iodide $(1 \mathrm{M})$ and hydrochloric acid $(2 \mathrm{M})$ mixed solution as supporting electrolyte. An $\mathrm{Ag} / \mathrm{AgCl}$ electrode was employed as the reference electrode and a $\mathrm{Pt}$ wire served as the counter electrode. $\mathrm{CV}$ was recorded from 0 to $0.5 \mathrm{~V}$ vs. $\mathrm{Ag} / \mathrm{AgCl}$ at low scan rates and from -0.2 to $0.8 \mathrm{~V}$ vs. $\mathrm{Ag} / \mathrm{AgCl}$ at high scan rates. The cell resistance was also measured immediately after $\mathrm{CV}$ test, and the real part of the impedance at $1 \mathrm{kHz}$ was taken as the cell internal resistance from the AC impedance spectrum. All the $\mathrm{CV}$ curves were plotted based on the internal resistance (IR)-corrected data.

Diffusion coefficient $\left(D_{o}\right)$ measurement.-Diffusion coefficient can be calculate by Randles-Sevcik Equation $7:^{13}$

$$
i_{p}=\left(2.69 \times 10^{5}\right) \mathrm{n}^{3 / 2} \mathrm{ACD}_{0} \nu^{1 / 2}
$$

where $i_{p}$ is the peak current, $\mathrm{n}$ is the number of electrons, $\mathrm{A}$ is the reaction area $\left(\mathrm{cm}^{2}\right), \mathrm{C}$ is the concentration of reactants $\left(\right.$ mole $\left.\mathrm{cm}^{-3}\right)$, $\mathrm{D}_{0}$ is the diffusion coefficient $\left(\mathrm{cm}^{2} \mathrm{~s}^{-1}\right), v$ is the scan rate $\left(\mathrm{V} \mathrm{s}^{-1}\right)$.

Membrane electrode assembly preparation.-ODC electrolytic cell: Pt/C (60 wt $\%$, TKK) was used as catalysts both anode and cathode. A homogeneous ink consisted of Pt/C (60 wt\%, TKK), Nafion dispersion (5 wt\%, DuPont) and isopropanol was sprayed onto the microporous layer (MPL) of a commercially available gas diffusion layer (SGL25 BC, SGL Carbon Corp). The composition of the dry catalyst layers was $65 \mathrm{wt} \%$ catalyst $(\mathrm{Pt} / \mathrm{C})$ and $35 \mathrm{wt} \%$ Nafion. The platinum loading was $0.6 \mathrm{mg} \mathrm{cm}^{-2}$. Two pieces of electrode consisted of $\mathrm{Pt} / \mathrm{C}$ catalysts and Nafion ionomer and Nafion 117 membrane were assembled directly for ODC electrolytic cell. TIRC electrolytic cell: $\mathrm{Pt} / \mathrm{C}(60 \mathrm{wt} \%$, TKK) was used as the anode catalysts. The anode electrode was prepared: A homogeneous ink consisted of $\mathrm{Pt} / \mathrm{C}$ (60 $\mathrm{wt} \%$, TKK), PTFE emulsion (20 wt $\%$ ) and ethanol was coated on the microporous layer (MPL) of a commercially available gas diffusion layer (SGL25 BC, SGL Carbon Corp) using a blade, followed by calcining at $240^{\circ} \mathrm{C}$ for $30 \mathrm{~min}$ and $340^{\circ} \mathrm{C}$ for $30 \mathrm{~min}$ in $\mathrm{N}_{2}$ to form the electrode. The composition of the dry catalyst layers was $64 \mathrm{wt} \%$ catalyst (Pt/C) and $36 \mathrm{wt} \%$ PTFE. The platinum loading was $0.6 \mathrm{mg}$ $\mathrm{cm}^{-2}$. A stacked $(\times 3)$ carbon papers (TGP-H-060, Toray) were used as cathode electrode. Anode electrode, Nafion 212 membrane and cathode electrode were assembled directly to form MEA for TIRC electrolytic cell. HEC electrolytic cell: the anode and cathode electrodes were prepared according to TIRC electrolytic cell and ODC electrolytic cell method, respectively. Anode electrode, Nafion 117 membrane and cathode electrode were assembled directly to form MEA for HEC electrolytic cell.

Electrolytic cells evaluation test.-A $5 \mathrm{~cm}^{2}$ cell with graphite current collectors was used for all experiments (Fuel Cell Technologies). Anhydrous $\mathrm{HCl}$ gas was supplied to the anode at $50 \mathrm{ml} \mathrm{min}^{-1}$ through a rotameter. Oxygen with the humidity temperature of $60^{\circ} \mathrm{C}$ at $200 \mathrm{ml}$ $\mathrm{min}^{-1}$ was feed to the cathode of ODC electrolytic cell. Hydrochloric acid (1M, $200 \mathrm{ml})$ was supplied to the cathode of HEC electrolytic cell at $200 \mathrm{ml} \mathrm{min}^{-1}$ by a peristaltic pump. An aqueous solutions (200 $\mathrm{ml})$ consisted of iodine $(1 \mathrm{M})$, potassium iodide $(1 \mathrm{M})$ and hydrochloric acid ( $2 \mathrm{M})$ were magnetically stirred and supplied to the cathode

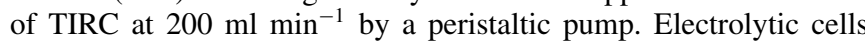
were operated at $40^{\circ} \mathrm{C}$ at atmospheric pressure. The electrochemical measurements were performed by a power supply (BK9171, BK Precision). For HEC and ODC electrolytic cells, voltage-current curves (U-I curve) were recorded after 30 min activation operation. For TIRC electrolytic cell, U-I curves were recorded at different $\mathrm{I}_{3}{ }^{-}$oxidation depth. The different $\mathrm{I}_{3}{ }^{-}$oxidation depth were charged at constant current mode and determined by sodium thiosulfate $(0.1 \mathrm{M})$ titration.

Coulombic efficiency measurement.-Coulombic efficiency was determined using Iodometry test. ${ }^{14}$ The mixed gas (chlorine and $\mathrm{HCl}$ ) exited from the anode of cell was absorbed by a potassium iodide solution $(50 \mathrm{ml}, 3 \mathrm{~g} \mathrm{KI})$ for $5 \mathrm{~min} .10 \mathrm{ml}$ of the samples was extracted 
(a)

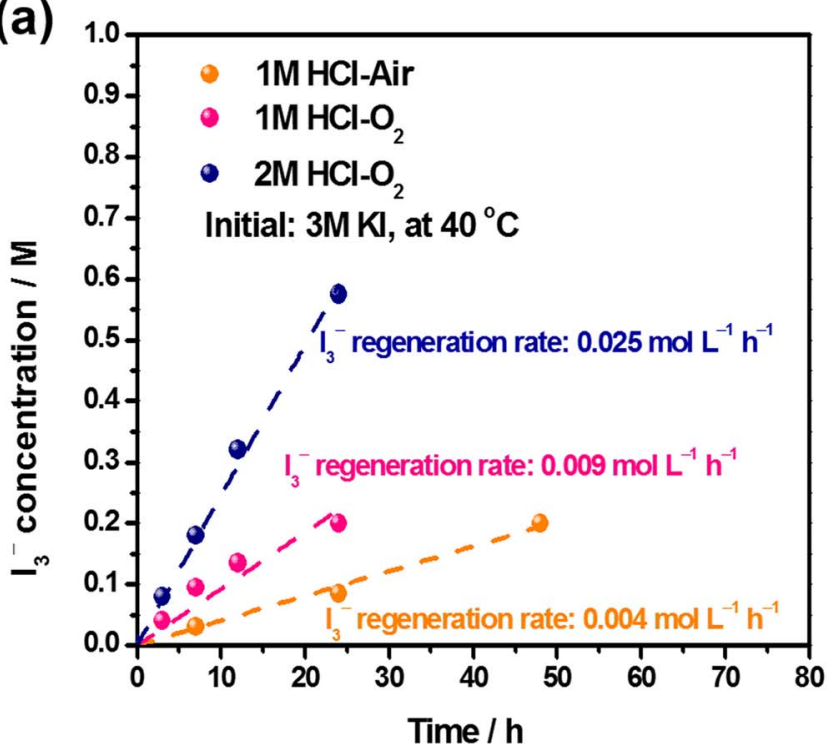

(c)

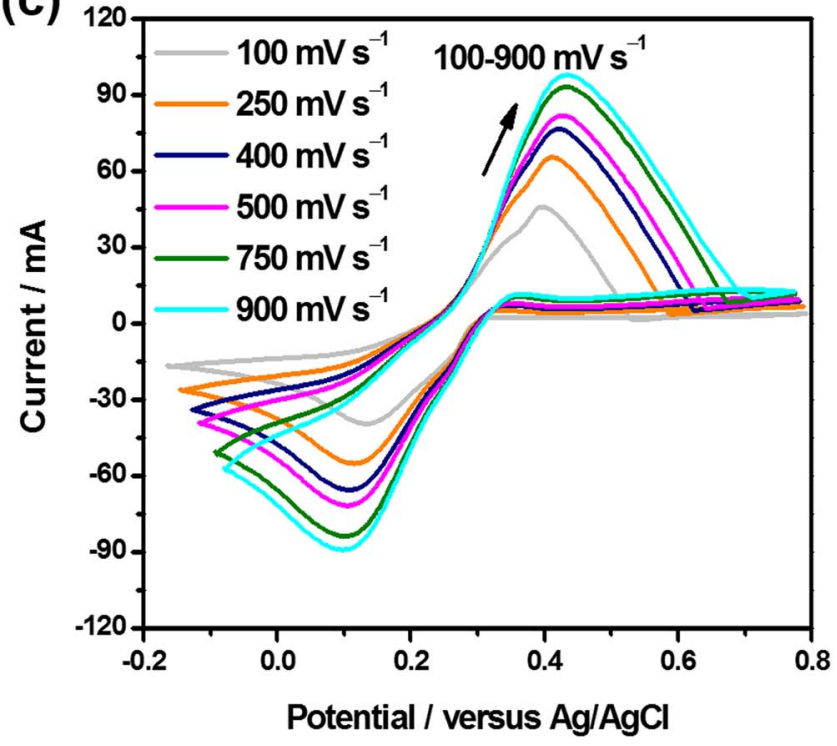

(b)

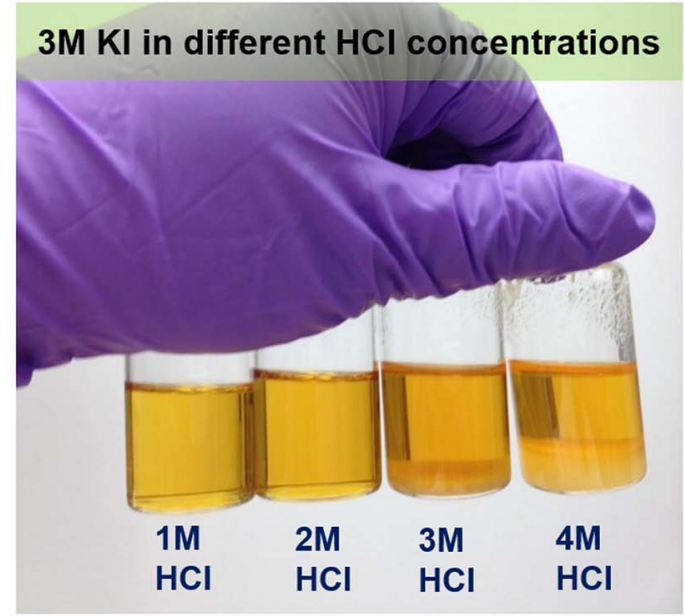

(d)

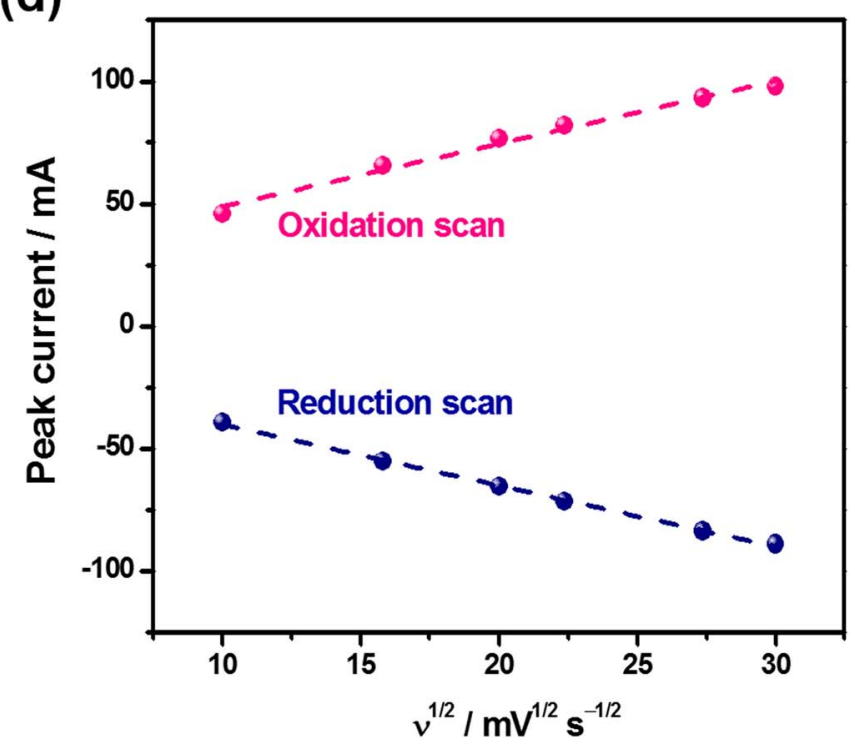

Figure 2. (a) The concentration of regenerated $\mathrm{I}_{3}{ }^{-}$versus oxidation time in $1 \mathrm{M}$ or $2 \mathrm{M} \mathrm{HCl}$ solution by bubbling air or pure oxygen. (b) Digital photo of $3 \mathrm{M}$ KI solution with different $\mathrm{HCl}$ concentrations. (c) $\mathrm{CV}$ curves of $\mathrm{I}_{3}{ }^{-} / \mathrm{I}^{-}$at different scan rates: 100 (gray), 250 (orange), 400 (navy), 500 (magenta), 750 (olive) and 900 (cyan) $\mathrm{mV} \mathrm{s}^{-1}$. (d) Oxidation (top, pink) and reduction (bottom, navy) peak currents from c against the square root of scan rate.

and titrated by $0.1 \mathrm{M}$ sodium thiosulfate to calculate the moles of chlorine produced. Coulombic efficiency was then calculated using Equation 8.

Coulombic efficiency

$$
=\frac{\mathrm{Cl}_{2} \text { produced }(\mathrm{mol}) \times 2 \times \text { Faraday constant }(\mathrm{C} / \mathrm{mol})}{\text { Current }(\mathrm{A}) \times \text { time }(\mathrm{s})}
$$

TIRC electrolytic cell durability test.-A $5 \mathrm{~cm}^{2}$ cell with graphite current collectors was used for all experiments (Fuel Cell Technologies). Anhydrous $\mathrm{HCl}$ gas was supplied to the anode at $50 \mathrm{ml} \mathrm{min}{ }^{-1}$ through a rotameter. A catholyte solution $(1.5 \mathrm{~L}$, theoretical calculation based on $\mathrm{I}_{3}{ }^{-}$regenerated rate to keep $100 \% \mathrm{I}_{3}{ }^{-}$oxidation depth) consisted of iodine $(1 \mathrm{M})$, potassium iodide $(1 \mathrm{M})$ and hydrochloric acid ( $2 \mathrm{M}$ ) were magnetically stirred and supplied to the cathode of TIRC at $200 \mathrm{ml} \mathrm{min}^{-1}$ by a peristaltic pump. Oxygen was bubbled to the bottom of the catholyte. Electrolytic cells were operated at $40^{\circ} \mathrm{C}$ at atmospheric pressure. The voltage was recorded at the current density of $4 \mathrm{kA} \mathrm{m}^{-2}$ every hour.

\section{Results and Discussion}

As proof of concept, we investigated both the chemical and electrochemical processes. $\mathrm{I}_{3}{ }^{-}$regeneration was investigated by oxidizing $\mathrm{I}^{-}$with air or pure oxygen. Pure oxygen resulted in expectedly faster regeneration under the same conditions (oxygen: $0.009 \mathrm{~mol} \mathrm{~L}^{-1} \mathrm{~h}^{-1}$, air: $0.004 \mathrm{~mol} \mathrm{~L}^{-1} \mathrm{~h}^{-1}$, in $1 \mathrm{M} \mathrm{HCl}$ and $40^{\circ} \mathrm{C}$; Figure $2 \mathrm{a}$ ). The regeneration rate can be further improved by increasing $\mathrm{HCl}$ concentration $\left(0.025 \mathrm{~mol} \mathrm{~L}^{-1} \mathrm{~h}^{-1}\right.$ at $2 \mathrm{M} \mathrm{HCl}$ and $\left.40^{\circ} \mathrm{C}\right)$. Note that $\mathrm{HCl}$ concentration was not increased beyond $2 \mathrm{M}$ due to decreasing solubility of potassium iodide (Figure $2 \mathrm{~b}$ ).

The electrochemisty of $\mathrm{I}_{3}{ }^{-} / \mathrm{I}^{-}$redox was studied by $\mathrm{CV}$. Figure $2 \mathrm{c}$ shows both $\mathrm{I}_{3}{ }^{-}$reduction and $\mathrm{I}^{-}$oxidation, sequentially, at different scan rates. As expected, the potential separation between the reduction peak and oxidation peak slightly increased with scan rate. The ratio 


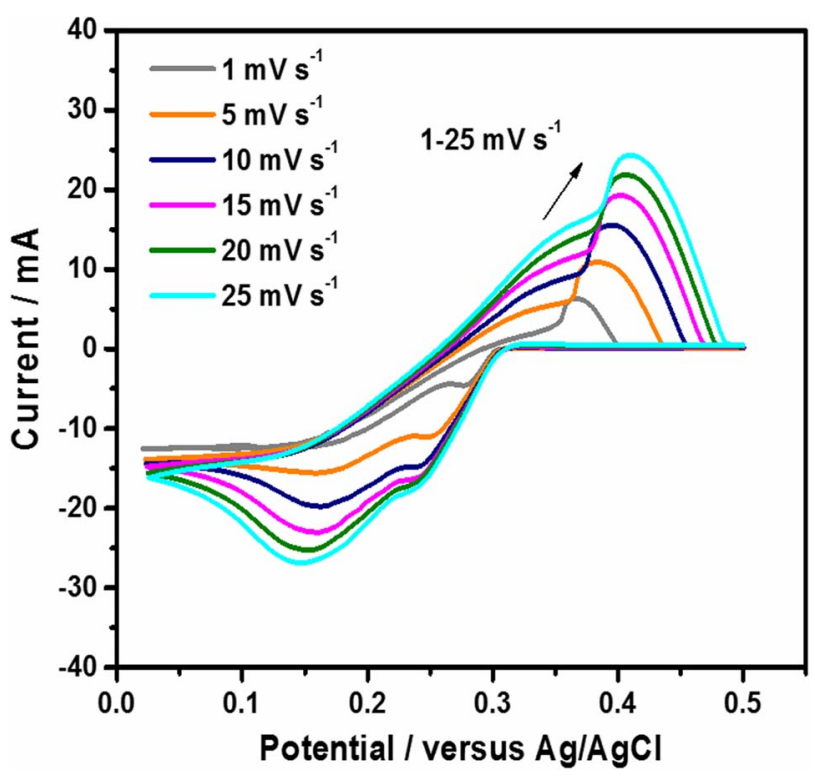

Figure 3. $\mathrm{CV}$ curves of $\mathrm{I}_{3}^{-} / \mathrm{I}^{-}$at different scan rates: 1 (gray), 5 (orange), 10 (navy), 15 (magenta), 20 (olive) and 25 (cyan) $\mathrm{mV} \mathrm{s}^{-1}$.
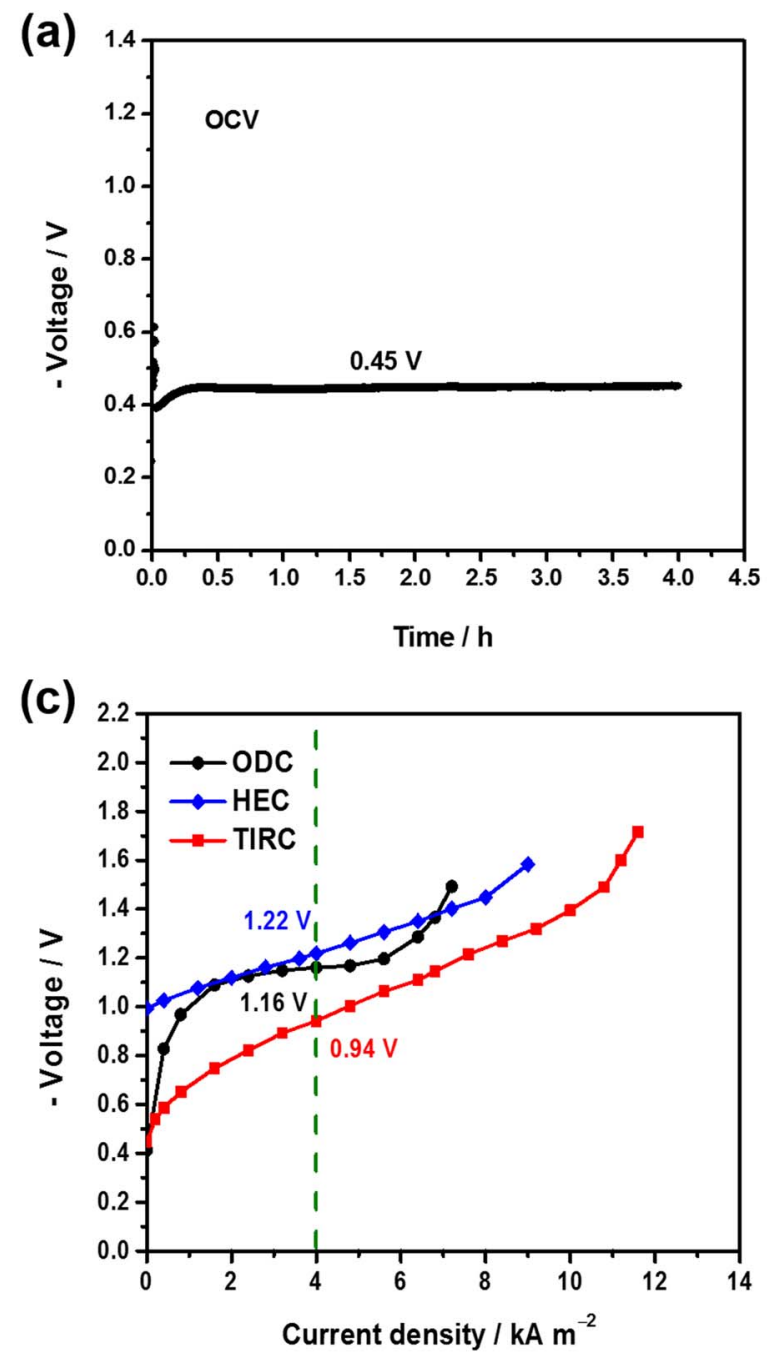

of anodic to cathodic peak current $\left(\mathrm{I}_{\mathrm{pa}} / \mathrm{I}_{\mathrm{pc}}\right)$ approaches unity $(\sim 1.0)$, indicating excellent coulombic reversibility for the redox reaction. $\mathrm{I}_{3}{ }^{-}$ reduction is a two-electron process, ${ }^{15,16}$ which is also observed in this work (two reduction peaks can be observed at low scan rates, from 1 to $25 \mathrm{mV} \mathrm{s}^{-1}$, Figure 3 ). The oxidation and reduction peak currents are proportional to the square root of the scan rate $(\nu)$ (Figure $2 \mathrm{~d}$ ). The diffusion coefficient $\left(D_{0}\right)$ of $\mathrm{I}_{3}{ }^{-}$reduction was determined to be 2.79 $\times 10^{-7} \mathrm{~cm}^{2} \mathrm{~s}^{-1}$, which is consistent with other reports $(1.98-2.59 \times$ $\left.10^{-7} \mathrm{~cm}^{2} \mathrm{~s}^{-1}\right) .^{17}$

A TIRC-based electrolyzer was also evaluated. A stable OCV of $0.45 \mathrm{~V}$ was observed (Figure $4 \mathrm{a}$ ), consistent with the theoretical prediction $(0.45 \mathrm{~V})$ described in Eqns. 3 and 4. This OCV was much lower than that of an HEC-based electrolyzer $(0.99 \mathrm{~V})$ and comparable to that of an ODC-based one $(0.41 \mathrm{~V})$ under the same conditions (Figure 4c). HEC did not show a kinetically controlled regime, but still showed high operational voltage due to high standard voltage. Though ODC showed similar OCV to TIRC, the operational voltage increased rapidly even at current densities below $1 \mathrm{kA} \mathrm{m}^{-2}\left(100 \mathrm{~mA} \mathrm{~cm} \mathrm{~cm}^{-2}\right)$ due to sluggish ORR at the cathode. ${ }^{18}$ Taking advantage of TIRC, a lower cell voltage was achieved: $0.94 \mathrm{~V}$ vs. $1.16 \mathrm{~V}$ (ODC) and $1.22 \mathrm{~V}$ (HEC) at a typical current density of $4 \mathrm{kA} \mathrm{m}^{-2}$. This lower operational voltage leads to a $20-25 \%$ reduction in energy consumption (710 vs. 901 and $939 \mathrm{kWh}$ per ton $\mathrm{Cl}_{2}$ ), the lowest reported in the literature (Table I). ${ }^{7}$ (b)

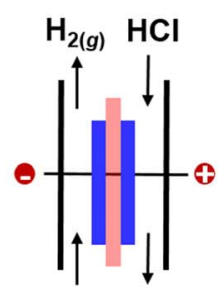

dilute $\mathrm{Cl}_{2(g)}$ $\mathrm{HCl}_{(a q)}$

HEC

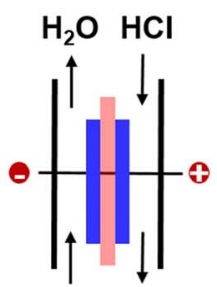

$\mathrm{O}_{2(g)} \mathrm{Cl}_{2(g)}$

ODC

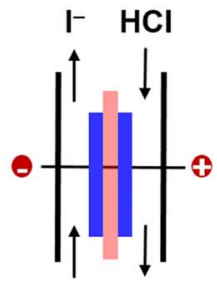

$\mathrm{I}_{3}{ }^{-} \quad \mathrm{Cl}_{2(g)}$

TIRC

(d)

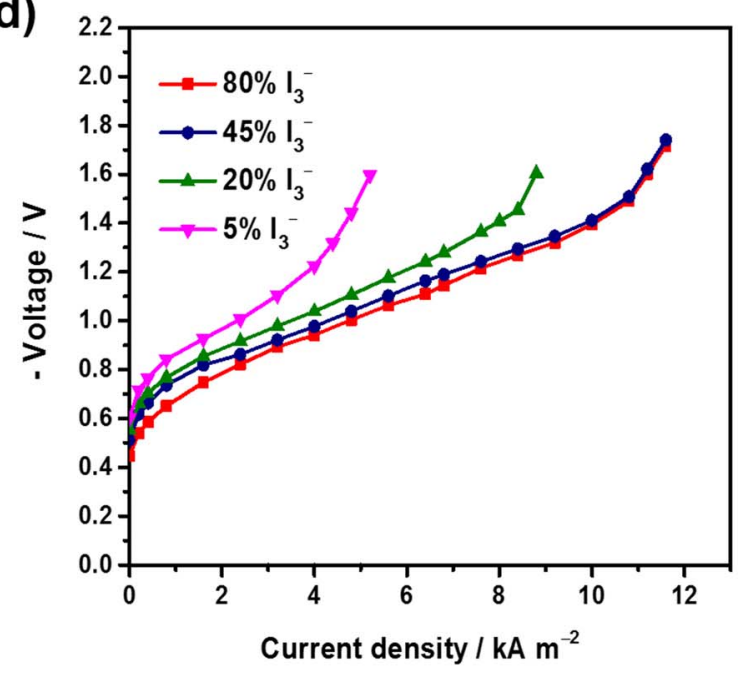

Figure 4. (a) OCV of TIRC at $40^{\circ} \mathrm{C}$. (b) Schematics of HEC, ODC and TIRC with gaseous $\mathrm{HCl}$ feedstock. (c) Performance comparison of HEC, ODC and TIRC (80\% oxidation depth, which is consisted of $0.8 \mathrm{~mol} \mathrm{~L}^{-1} \mathrm{I}_{3}^{-}$and $0.6 \mathrm{~mol} \mathrm{~L}^{-1} \mathrm{I}^{-}$in catholyte solution) with anhydrous $\mathrm{HCl}$ gas feedstock at $40^{\circ} \mathrm{C}$. (d) $\mathrm{U}-\mathrm{I}$ curves of TIRC with anhydrous $\mathrm{HCl}$ gas feedstock at different $\mathrm{I}_{3}{ }^{-}$oxidation depth at $40^{\circ} \mathrm{C}$. 
Table I. Comparison of the rivalling electrolysis processes for chlorine regeneration from $\mathrm{HCl}$.

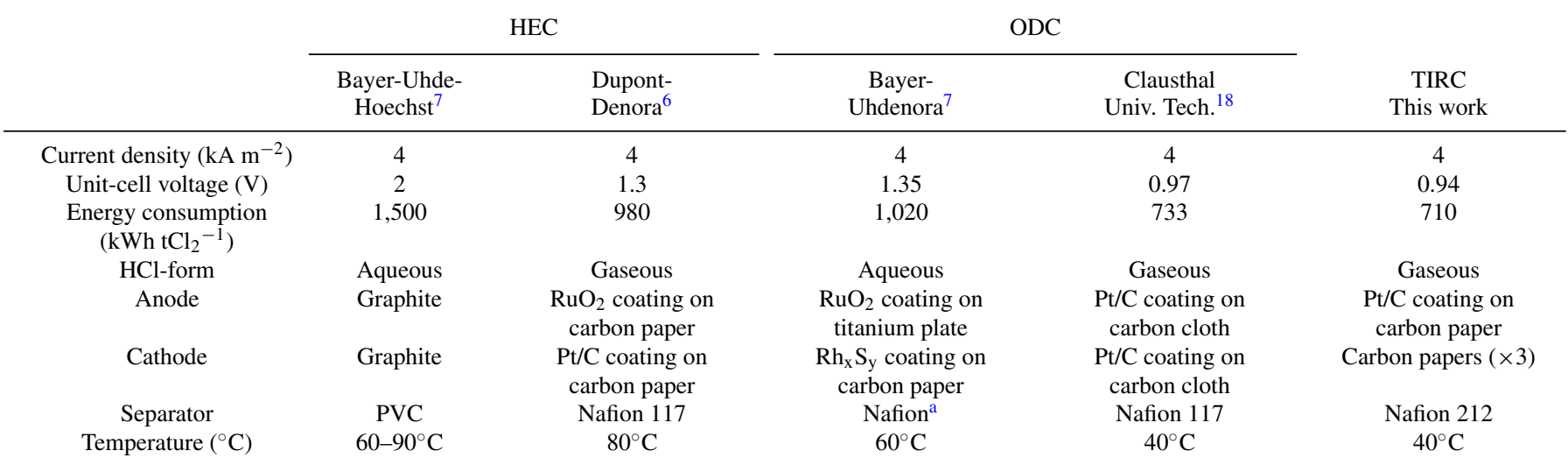

${ }^{a}$ Not known which type of Nafion.

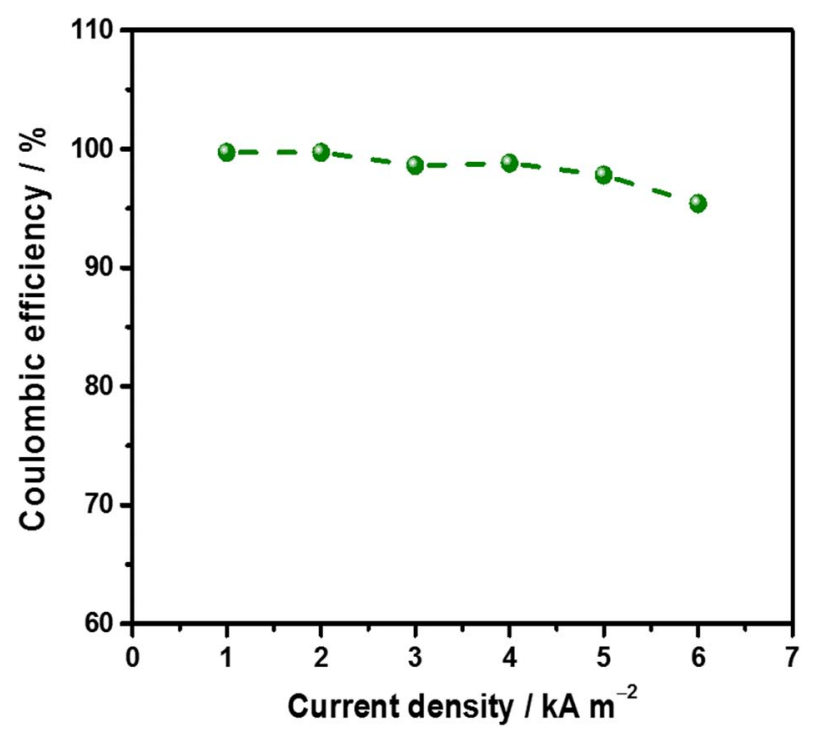

Figure 5. Coulombic efficiency of TIRC-based $\mathrm{HCl}$ electrolyzer versus current density at $40^{\circ} \mathrm{C}$.

(a)

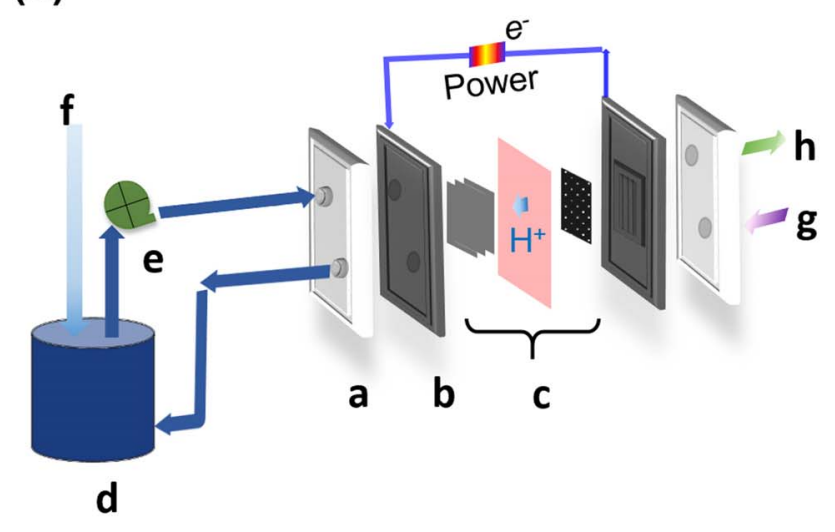

The performance of TIRC-based $\mathrm{HCl}$ electrolyzer with different oxidation depths of $\mathrm{I}_{3}^{-} / \mathrm{I}^{-}$in the catholyte was investigated (Figure $4 d)$. For oxidation depths of $20-80 \%$, operational voltage was maintained between 0.94 and $1.04 \mathrm{~V}$. Note that high oxidation depth is required for TIRC to deliver high electrolyzer performance; for example, 5\% resulted in poor performance. In addition, TIRC offers high coulombic efficiency, e.g., 95.4-99.7\% at 1-6 kA m ${ }^{-2}$ (Figure 5), significantly above that of aqueous $\mathrm{HCl}$ electrolysis (e.g., 34-37\% at $\left.1-4 \mathrm{kA} \mathrm{m}^{-2}\right){ }^{19}$

Further, we carried out preliminary durability tests for the TIRC system by simultaneously bubbling oxygen into the catholyte tank (Figure 6a). Figure $6 \mathrm{~b}$ shows that the TIRC system worked continuously for 17 hours, with a slight operational voltage increase from 0.91 to $1.19 \mathrm{~V}$ at $4 \mathrm{kA} \mathrm{m}^{-2}$. Note that the durability of TIRC system can be improved by optimizing electrolyzer/components such as adopting durable anode catalyst, and the energy efficiency can be further enhanced by engineering the design of chemical reactor.

\section{Conclusions}

In summary, $\mathrm{I}_{3}{ }^{-} / \mathrm{I}^{-}$redox-mediated cathode electrolysis was proposed and implemented for the first time for converting anhydrous

(b)

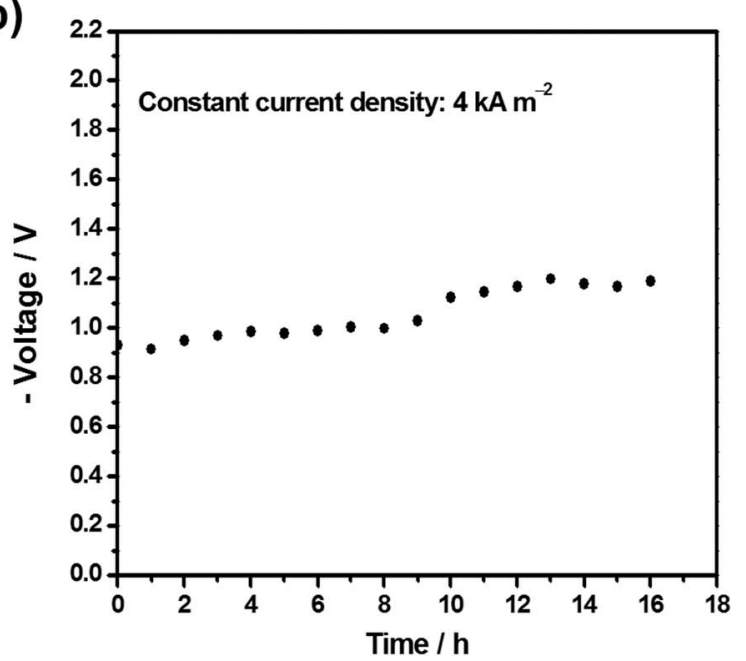

Figure 6. (a) Schematic illustrating structure of TIRC process, a: current collector plate, b: graphite plate with channel, c: membrane-electrode-assembly (MEA, Nafion 212 as proton exchange membrane, anode made of carbon paper with hydrophobic microporous layer loaded with $\mathrm{Pt} / \mathrm{C} \mathrm{catalyst}\left(0.6 \mathrm{mg} \mathrm{Pt} \mathrm{cm}^{-2}, 36 \mathrm{wt} \%\right.$

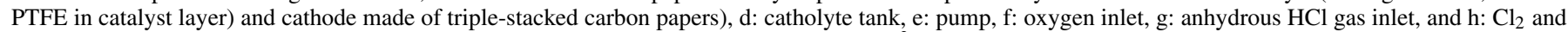
$\mathrm{HCl}$ outlet. (b) Preliminary durability test of TIRC system at the current density of $4 \mathrm{kA} \mathrm{m}^{-2}$ at $40^{\circ} \mathrm{C}$. 
$\mathrm{HCl}$ gas to $\mathrm{Cl}_{2}$. A low cell voltage was achieved due to the due to its redox potential and fast $\mathrm{I}_{3}{ }^{-}$reduction reaction compared to conventional HEC or ODC processes, reducing energy consumption by $20 \%-25 \%$ at a typical current density of $4 \mathrm{kA} \mathrm{m}^{-2}$. Cell optimization and reactor engineering may further improve the durability and efficiency.

\section{Acknowledgments}

The financial support for this work is provide by DEGi Chlorine.

\section{References}

1. I. Moussallem, J. Jörissen, U. Kunz, S. Pinnow, and T. Turek, J Appl Electrochem, 38(9), 1177 (2008).

2. F. Wattimena and W. M. H. Sachtler, in Studies in Surface Science and Catalysis, T. Seiyama and K. Tanabe, eds., Vol. 7, Part B, p. 816, Elsevier, (1981).

3. J. Perez-Ramirez, C. Mondelli, T. Schmidt, O. F. K. Schluter, A. Wolf, L. Mleczko, and T. Dreier, Energy \& Environmental Science, 4(12), 4786 (2011).

4. M. Mortensen, R. G. Minet, T. T. Tsotsis, and S. Benson, Chemical Engineering Science, 51(10), 2031 (1996).

5. C. G. L. James A. Trainham, John S. Newman, Kenneth B. Keating, and Douglas J. Eames, US 5,411,641, (1995).
6. D. J. Eames and J. Newman, Journal of The Electrochemical Society, 142(11), 3619 (1995).

7. I. G. Martinez, T. Vidaković-Koch, R. Kuwertz, U. Kunz, T. Turek, and K. Sundmacher, Electrochimica Acta, 123(0), 387 (2014).

8. Fank S. Low Bronxville, US 2,468,766, (1949).

9. J. Durst, C. Simon, F. Hasche, and H. A. Gasteiger, Journal of the Electrochemical Society, 162(1), F190 (2015).

10. U. A. Paulus, T. J. Schmidt, H. A. Gasteiger, and R. J. Behm, Journal of Electroanalytical Chemistry, 495(2), 134 (2001).

11. Z. Liu, Y. D. Wang, X. P. Ai, W. M. Tu, and M. Pan, Sci Rep, 4, (2014).

12. P. Hasin, M. A. Alpuche-Aviles, Y. Li, and Y. Wu, The Journal of Physical Chemistry $C, 113(17), 7456$ (2009).

13. Y. Zhao, L. Wang, and H. R. Byon, Nat Commun, 4, 1896 (2013).

14. T. Mirzazadeh, F. Mohammadi, M. Soltanieh, and E. Joudaki, Chemical Engineering Journal, 140(1-3), 157 (2008).

15. B. Li, Z. Nie, M. Vijayakumar, G. Li, J. Liu, V. Sprenkle, and W. Wang, Nat Commun, 6 (2015).

16. Y. Zhao, M. Hong, N. B. Mercier, G. H. Yu, H. C. Choi, and H. R. Byon, Nano Lett, 14(2), 1085 (2014).

17. M. L. Chen, S. L. Huang, C. L. Hsieh, J. Y. Lee, and T. J. Tsai, Electrochimica Acta, 141(0), 241 (2014).

18. R. Kuwertz, I. Gonzalez Martinez, T. Vidaković-Koch, K. Sundmacher, T. Turek, and U. Kunz, Electrochemistry Communications, 34(0), 320 (2013).

19. F. Mohammadi, S. N. Ashrafizadeh, and A. Sattari, Chemical Engineering Journal, 155(3), 757 (2009). 